\title{
Mycobacterium leprae: A historical study on the origins of leprosy and its social stigma
}

\author{
Luigi Santacroce ${ }^{1,2}$, Raffaele Del Prete ${ }^{1}$, Ioannis Alexandros Charitos ${ }^{2}$, Lucrezia Bottalico ${ }^{2}$ \\ ${ }^{1}$ Department of Interdisciplinary Medicine, Section of Microbiology, Policlinico University Hospital of Bari, Italy; \\ ${ }^{2}$ CEDICLO - Interdepartmental Research Center for Pre-Latin, Latin and Oriental Rights and Culture Studies, \\ University of Bari, Italy
}

Article received 23 April 2020; accepted 5 September, 2021

\section{SUMMARY}

This article aims to investigate about the social stigma and the prejudice of society towards the patients with leprosy, but also to understand how this infectious disease has largely influenced human lifestyle and evolution analyzing the evolution of its treatments from past empirical treatments to actual multidrug therapy (MDT).

References on leprosy were extensively searched in literature using PubMed, Web of Science, Medline, Springer link and Elsevier's (EMBASE.com) databases, but also in medical, religious and archaeological books. Leprosy's spread all around the world following human paths of migration from the African Continent to the Asian one and to Europe, instead its appearance in the New Continent is more recent. Wars, unhygienic conditions, social and health inequality created conditions for its spread since prehistorical times, and existing health disparities contributed to unequal morbidity and mortality, before its gradual decline after the Middle Ages due to the raise of other worse pandemics. Starting from Renaissance, a deeper knowledge on its pathophysiological mechanisms brought an increasingly advanced combined surgical and pharmacological treatment, but still in modern times many efforts have been made to erase its social stigma, changing its name in "Hansen's disease" included.

Keywords: Leprosy, Mycobacterium leprae, history of medicine, history of leprosy, palaeopathology, infectious diseases, renaissance medicine and therapy.

\section{INTRODUCTION}

T eprosy (or Hansen's disease) is considered Las one of the oldest infectious diseases ever known in human history: it has been the scourge of humanity since antiquity. Understanding historical features of Hansen's disease can be helpful to better understand the social stigma associated with this infectious disease, analyzing how patients afflicted with leprosy were inhumanely treated for over many centuries, and how the medical approach to the patients changed from

$\overline{\text { Corresponding author }}$

Ioannis Alexandros Charitos

E-mail: alexanestesia@hotmail.com the ancient societies to the modern Era. For a long time, Hansen's disease was thought to be a punishment from God. The disease affects skin and nerves with severe destructive effects. The physical impairments caused by the illness and the devastating effects on skin and nerves brought prejudice, fear and segregation in all societies since ancient times: patients with Hansen's disease were socially isolated and forced to live in poverty and loneliness.

\section{MATERIALS AND METHODS}

An extensive search for historical papers and textbooks on the topic of interest was carried out for a narrative review from the early history of leprosy to date. We included historical papers 
and reviews by using the search engines PubMed, Web of Science, Medline, Springer link, Elsevier's (EMBASE.com) with several keywords (Leprosy, Mycobacterium leprae, History of medicine, History of leprosy, Palaeopathology, Renaissance medicine and therapy), original documents from Greek historical online archives. We searched literature containing medical and/or surgical descriptions on leprosy management in antiquity, written in English or translated into English from a foreign language (Chinese, Indian, Greek and Latin), but also in the polytonic orthography of ancient Greek. We researched original sources in the National Library of Greece (Stavros Niarchos Foundation, Athens) and in the Library of the school of Health Sciences of the National and Kapodistrian University of Athens (Greece). Abstracts in original language (followed by English translation) of some of the most representative texts were provided in order to better understand its historical and medical meaning, avoiding a secondary reference, but also to allow other native speakers scholars to formulate their personal hypothesis on terms and items in ancient languages whose interpretations is still debated. Fifty-one documents were eligible for the study, dating from the ancient Classical age manuscripts to 2020. Papers were included for their medical and historical relevance about leprosy diagnosis and treatment throughout the ages, comparing medical knowledge of different medical cultures all over the world. Particularly, we selected documents and books which were best focused on detailed descriptions of leprosy. Papers and original medical

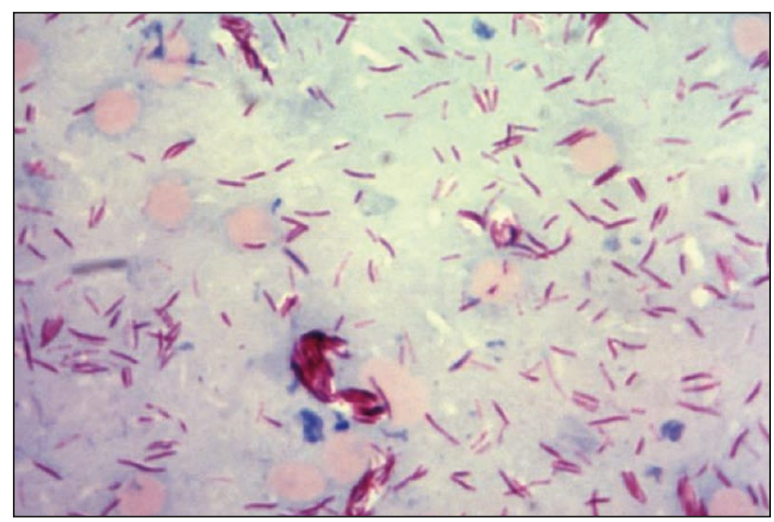

Figure 1 - Mycobacterium leprae (acid-fast, red rod bacilli), Shepard cold stain method. Courtesy of CDC-PHIL (image id \#21432). texts with historical relevance investigating descriptions, prevalence, clinical features, diagnosis and treatment throughout the ages made by ancient physicians were included. Their findings were assimilated, starting with ancient times to conclude with the most recent discoveries about this infectious disease.

Leprosy is caused by a bacillus, Mycobacterium leprae (Figure 1). It is an intracellular, aerobic, acid-fast, rod-shaped bacillus, surrounded by the characteristic waxy coating, which is one of the most important virulence factors [1].

The evolution of $M$. leprae is strongly linked with human evolution; in fact, the ancestors of $M$. leprae and $M$. tuberculosis have been estimated to have separated 36 million years ago $[2,3]$. The microorganism was discovered by Dr. Gerhard Armauer Hansen in 1874, a Norwegian physician who was searching for the unknown bacteria in the skin nodules of lepers, so the illness was called "Hansen's disease" [4]. He refuted, through his researches, the hereditary hypothesis regarding its human-to-human transmission, as was previously believed, while he claimed its transmission via droplets during close and frequent contact with untreated lepers. The disease mainly affects the skin, the peripheral nerves, mucosa of the upper respiratory tract, and the eyes, causing progressive and permanent damage to these organs and system if untreated [1]. These physical injuries, the facial transfiguration and the severe disability it caused were at the base of the terrible social mark associated to lepers.

Leprosy is a very ancient disease, described in the literature of antique civilizations; despite this, it is impossible to exactly establish where or when it emerged and spread throughout the Continents: probably it may have developed simultaneously in more than one area of the world.

For the first time, leprosy has been described in osteo-archaeological remains founded in India and dated to 2000 BC [5]. Molecular studies have shown that the disease spread following the migration paths of the first human groups from East Africa towards Asia and established itself in eastern and central Europe as well as in the Mediterranean Basin about 40,000 years ago and in the Americas in the last 500 years ago [6, 7]. This result suggests that even the last Neanderthals and the first Homo sapiens had contact with M. leprae (Figure 2). 


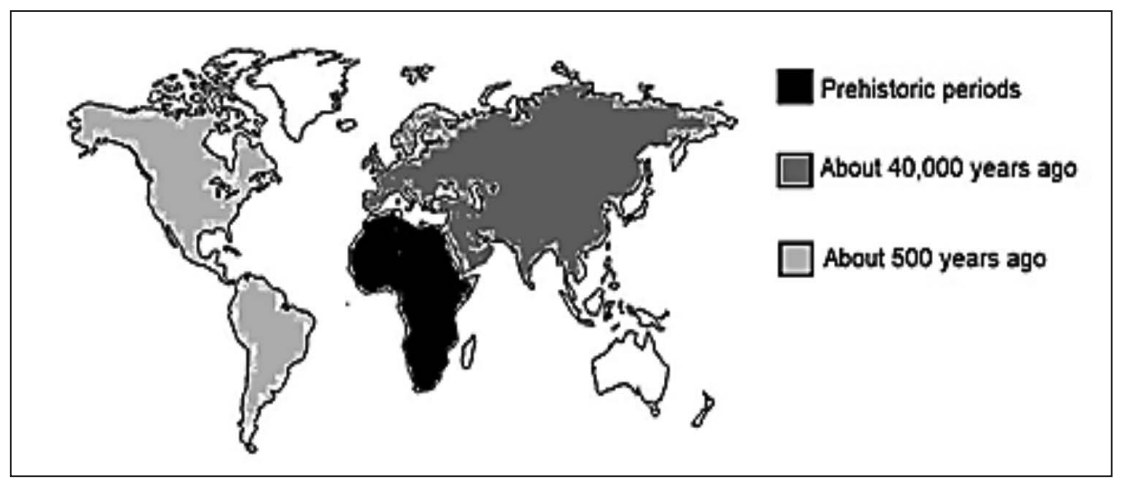

Figure 2 - World map representing the results of the Mycobacterium leprae's DNA quantification in paleontological finds on the continents in relation to the years.

First references about leprosy in the Indian, Egyptian and Chinese literature

Many old manuscripts suggest that leprosy existed in India, China and Africa since ancient times: references to leprosy are reported in the ancient literature of these countries. However, all these accounts, as well as many others, do not tell us exactly where Hansen's disease was first described and, probably, this will never be known. The term "Kushtha" was used in ancient Indian medicine to indicate skin diseases in general, including leprosy [5]. Nowadays, it is used in India specifically for leprosy. A reference to this term (Kushtha) is found in the Manu Smriti (Laws of Manu), which is considered to have been written from 500 to $1300 \mathrm{BC}$, and in the "Vedas", which are considered as of extreme antiquity, written around 1400 BC [8]. The great Indian leprologist Dharmendra is certain that a clear description of the clinical signs and treatment of Hansen's disease is contained in the "Sushruta Samhita", an ancient medical text written ca. $600 \mathrm{BC}$. In this text, under the "Kushtha" they included two sub-groups: the "Maha Kushtha" (or Major skin diseases) and the "Kshudra Kushtha" (or Minor skin diseases).

One variety of the first group, the "Arun-Kushtha", is considered the type of Kushtha which appears to refer to leprosy; it was characterized by slightly vermillion coloured patches on the skin, paresthesia, anesthesia and deformity of the limbs, suppuration of the affected part, breaking down of local skin, falling off of fingers, and sinking of nose $[8,9]$. Since ancient time, Indian physician used the Tuvarka seeds' oil as a potent remedy against leprosy as a drink or for rubbing the affected parts $[8,9]$. Most of the experts on Hindu medicine have identified Tuvarka oil with chaulmoogra oil, produced from the Indian plant Hydnocarpus kurzii (translated as Gynocardia-odorata by the earlier writers and as Taraktogenos-kurzii by the later writers). It was introduced into Western Medicine only recently but it continues to be sold in the Indian bazaars. Archaeologists found a reference to leprosy in the "Ebers" (written around 1550 BC) and "Brugsch" Papyri (dated between 1350-1200 $\mathrm{BC})$, under the term "Uchedu", describing leprosy among the slaves coming from Sudan [10]. In Canaan (Palestine), the moulding on a clay jar by Yoeli, which dates back to 1411-1314 BC, is frequently associated to leprosy because it is very similar to the leonine faces of Hansen's disease. However, for many historians this is a wrong interpretation: they consider the moulding just a grotesque decoration without any sense because they consider impossible that a jar associated with a such unaesthetic and unclean illness have been used by Egyptian for drinking water or for containing grain [11].

In ancient Chinese literature, there are no convincing references about the existence of leprosy. The "Nei Ching", considered the oldest medical text in existence, was written by Huang Ti (the Yellow Emperor), worshiped as the father of Chinese Medicine [12]. In this large medical text, probably written ca. $500 \mathrm{BC}$, he described many signs which could be associated with Hansen's disease, such as nodules, ulcerations, numbness and loss of eyebrows. A similar description of a probable case of leprosy was found in the "Secret Prescriptions" by Hua Tuo (ca. 140-208), a Chinese physician and surgeon who lived during the late Eastern Han dynasty; he mentioned white and red spots on the skin of a patient, anesthesia, blindness, ulcerations of the feet, loss of eyebrows, hoarseness and deformities [13, 14]. 
Leprosy in the Classical and Middle ages

Hansen's disease was brought into the Mediterranean countries of Europe at an earlier date. Many historians think that leprosy was introduced into Greece by the troops of Darius of Persia during the $4^{\text {th }}$ century BC and then the troops of Greek Mace-

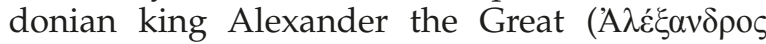

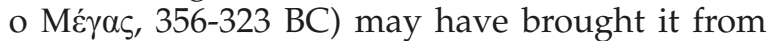
India to Egypt in the $5^{\text {th }}$ century BC. Indeed, the

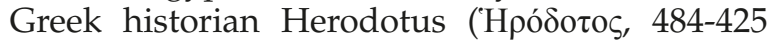

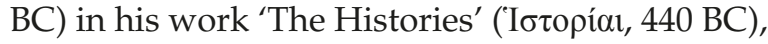
disease referring to the Persian population in Book I, chapter 138, writes about leprosy: [15]

"... The citizen who has leprosy or the white sickness may not come into a town or consort with other Persians. They say that he is so afflicted because he has sinned in some wise against the sun. Many drive every stranger, who takes such a disease, out of the country; and so they do to white doves, for the reason after this. Rivers they chiefly reverence; they will neither make water nor spit nor wash their hands therein, nor suffer anyone so to do ..."

Reference to leprosy is found in the Bible, particularly in the Old Testament with the Hebrew word "zaraath". The term was then translated from Hebrew to Greek, ca. 300 BC, as "lepra" in the New Testament and then into "leprosy" in the current language. The terrible biblical descriptions of the illness consequences are responsible for much of the stigma attached to leprosy that still exists today [16].

Some descriptions in the Hippocrates and then Aristotle's texts probably are referred to patients affected with leprosy, but the opinion of Hansen's disease experts is that neither man had a real knowledge of the disease. Later it is described by Aulus Cornelius Celsus (25 BC-37AD), Pliny the Elder (23-79 AD), Rufus of Ephesus ('Poṽpos

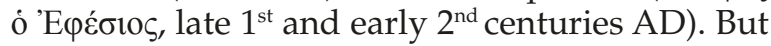
the first accurate description of the disease was

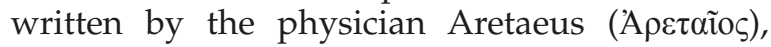
around $150 \mathrm{AD}$, one of the most celebrated of the ancient Greek physicians of the $1^{\text {st }}$ century AD; he was born in Greece, he studied medicine in Alexandria and practiced in Rome; he is generally

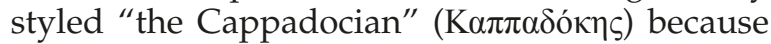
he was citizen of Cappadocia, a Roman province in Asia Minor. Aretaeus's work is summarized in eight books in the Ionic dialect, distinguishing the diseases in acute and chronic and the same does also for their therapeutic treatment. Indeed, in the general treaties for the chronic diseases

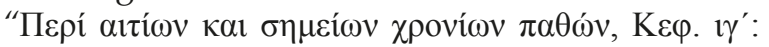

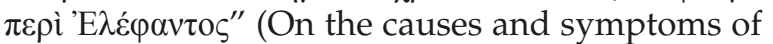
chronic disease, in Book II, Chapter XIII: On Elephas) [17-21], he described with great accuracy leprosy called as "E $\mathrm{\lambda} \varepsilon \dot{\varphi} \varphi \alpha \tau \tau o \varsigma^{\prime}$ " (Elephant), referring probably for the thickness of the skin that the disease causes or for the severity of symptoms, as not fatal and transmitted through the respiratory root, with large nodules and ulcers of the fingers, knees and cheeks and absorption of fingers and toes, but also he made a suggestive description of the leonine face of the lepers ones:

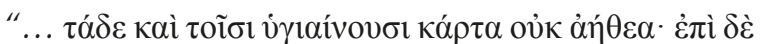

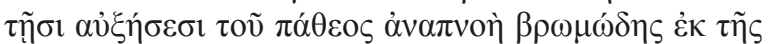

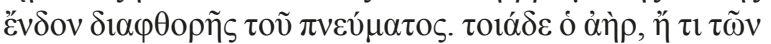

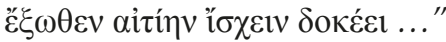

("... But upon the increase of the affection, the respiration is fetid from the corruption within of the breath (pneuma). The air, or something external, would seem to be the cause of this ...")

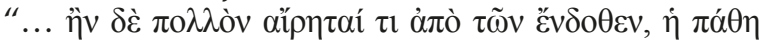

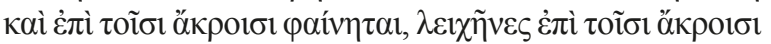

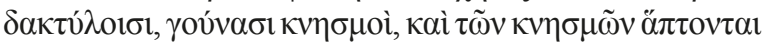

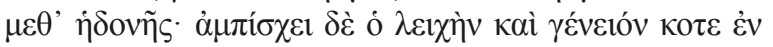

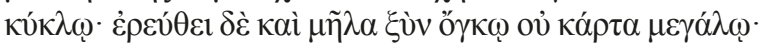

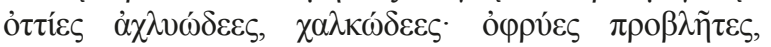

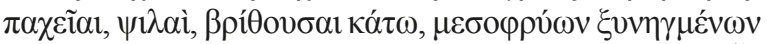

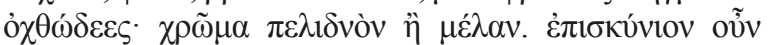

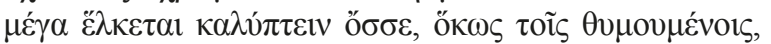

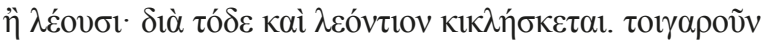

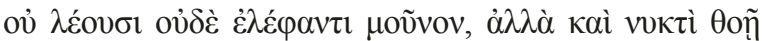

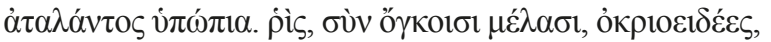

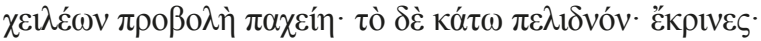

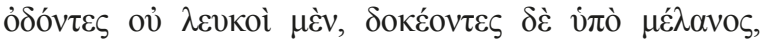

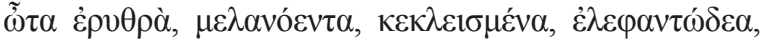

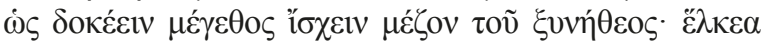

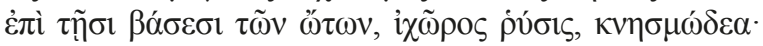

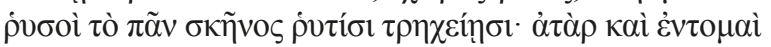

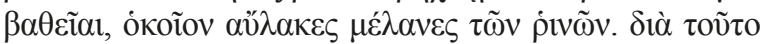

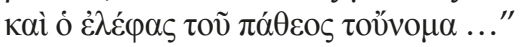

("... And the lichen sometimes embraces the chin all round; it reddens the cheeks, but is attended with no great swelling; eyes misty, resembling bronze; eyebrows prominent, thick, bald, inclining downwards, tumid from contraction of the intermediate space; colour livid or black; eye-lid, therefore, much retracted to cover the eyes, as in enraged lions; on this account it 
is named leontium. Wherefore it is not like to the lions and elephants only, but also in the eye-lids "resembles swift night." Nose, with black protuberances, rugged; prominence of the lips thickened, but lower part livid; nose elongated; teeth not white indeed, but appearing to be so under a dark body; ears red, black, contracted, resembling the elephant, so that they appear to have a greater size than usual; ulcers upon the base of the ears, discharge of ichor, with pruritus; shriveled all over the body with rough wrinkles; but likewise deep fissures, like black furrows on the skin; and for this reason the disease has got the name of elephas ...")

Aretaeus of Cappadocia wrote another treatise, as we have mentioned, about therapies of chronic diseases "X

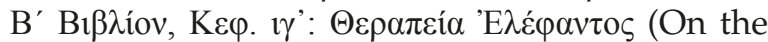
therapeutics of chronic disease, Book II, chapter XIII: cure of Elephas) [18]; in this text, he referred to some possible remedies to treat lepers:

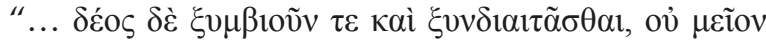

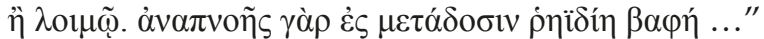

"... and, moreover, there is a danger in living or associating with it no less than with the plague, for the infection is thereby communicated by the respiration ..."

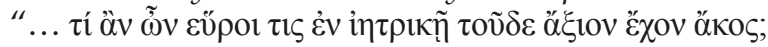

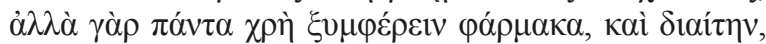

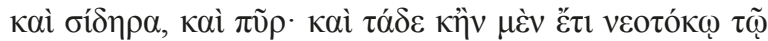

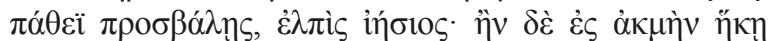

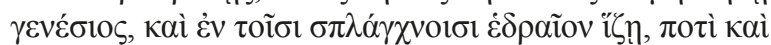

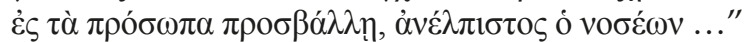
"... Wherefore what sufficient remedy for it shall we find in medicine? But yet it is proper to apply every medicine and method of diet, -- even iron and fire, -- and these, indeed, if you apply to a recent disease there is hope of a cure. But if fully developed, and if it has firmly established itself in the inward parts, and, moreover, has attacked the face, the patient is in a hopeless condition ..."

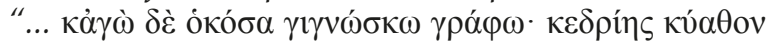

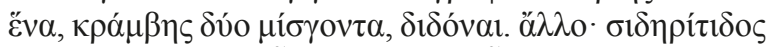

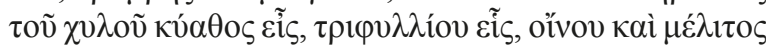

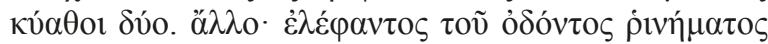

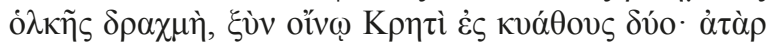

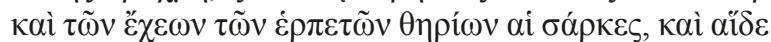

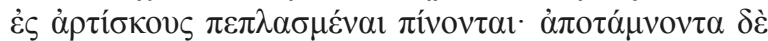

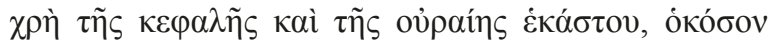

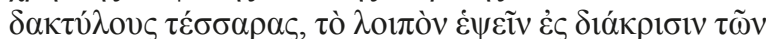

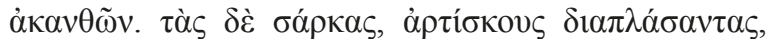

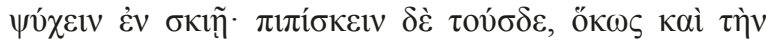

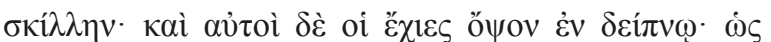

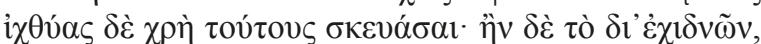

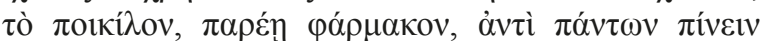

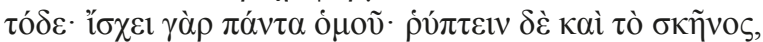

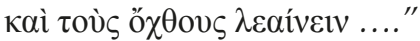

"... And I will now describe those with which I am acquainted. Mix one cyathus of cedria and two of brassica, and give. Another: Of the juice of sideritis, of trefoil one cyathus, of wine and honey two cyathi. Another: Of the shavings of an elephant's tooth one dram with wine, to the amount of two cyathi. Another: Of the shavings of an elephant's tooth one dram with wine, to the amount of two cyathi. But likewise the flesh of the wild reptiles, the vipers, formed into pastils, are taken in a draught. From their heads and tail we must cut off to the extent of four fingers' breadth, and boil the remainder to the separation of the back-bones; and having formed the flesh into pastils, they are to be cooled in the shade; and these are to be given in a draught in like manner as the squill. The vipers, too, are to be used as a seasoner of food at supper, and are to be prepared as fishes. But if the compound medicine from vipers be at hand, it is t be drunk in preference to all others, for it contains together the virtues of all the others, so to cleanse the body and smooth down its asperities ..."

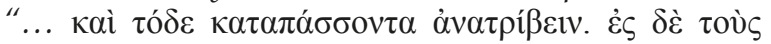

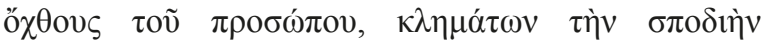

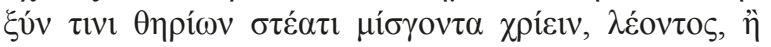

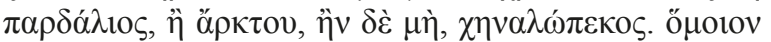

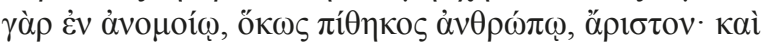

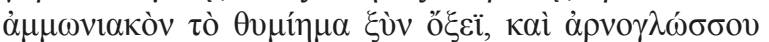

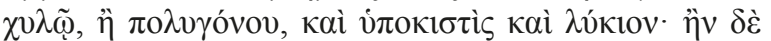

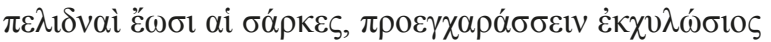

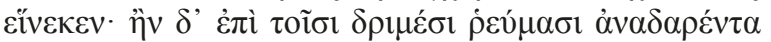

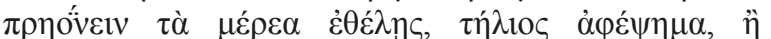

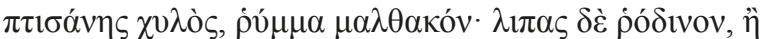

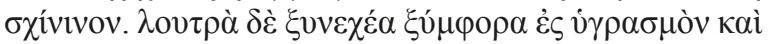
$\dot{\varepsilon} \varsigma \delta 1 \alpha \pi v 0 \eta े v \tau \tilde{\omega} v \kappa \alpha \kappa \tilde{\omega} v \chi v \mu \tilde{\omega} v . . . . "$

"... For the callous protuberances of the face, we are to rub in the ashes of vine branches, mixed up with the suet of some wild animal, as the lion, the panther, the bear; or if these are not at hand, of the barnacle goose; for like in the unlike, as the ape to man, is most excellent. Also, the ammoniac perfume with vinegar and the juice of plantain, or of knot-grass, and hypocistis and lycium. But if the flesh be in a livid state, scarifications are to be previously made for the evacuation of the humours. But if you wish to soothe the parts excoriated by the acrid defluxions, the decoction of fenugreek, or the juice of ptisan, will form an excellent detergent application; also the oil of roses or of lentisk baths are ap- 
propriate for humectating the body, and for dispelling the depraved humours..."

Several Greek physicians, including Galen (Г $\alpha \lambda \eta v o ́ s, 129-216 \mathrm{AD})$, described a disease that may have been leprosy, but they did not refer to the disease using the term Lepra $(\Lambda \dot{\varepsilon} \pi \rho \alpha)$, from which the modern term leprosy derived; instead,

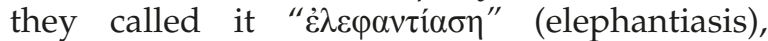
which will be later referred by their scholars as "elephantiasis graecorum". Galen wrote about the illness as it existed in the actual Germany. In his tractate "on leprosy" there are some references to the pre-modern therapy of leprosy: Galen's recommendations in the treatment of leprosy, which partly reports the thought of Aretaeus the Cappadocian, and wrote: "it is necessary to make use of the black vipers (snake meat) in food, drink, ointments and electuaries" and he explained also detailed instructions to its preparation "it should be boiled with scallions, dill, chickpeas and a little salt, and the juice might be enriched perhaps with some squab, until is good", but he cannot explain the specific efficacy of this remedy [22].

Galen refers to a cataplasm remedy the " $\delta$ ì $\chi \nu \lambda \tilde{\omega} v$ $\ddot{\varepsilon} \mu \pi \lambda \alpha \sigma \tau \rho v^{\prime \prime}$ (dia chylon emplastron) for the treatment of many types of ulcers and thus also for the $\dot{\varepsilon} \kappa \delta$ ópla (sores) of leprosy from the Greek physician Menecrates Tiberius Claudius Quirina

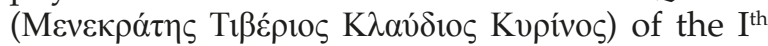

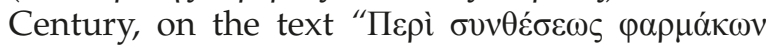

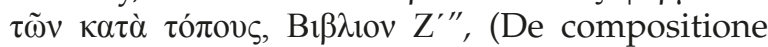
medicamentorum per genera, Book 7) and wrote:

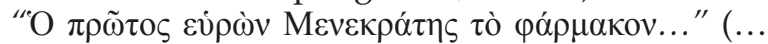
the first one who found the drug was Menecrates ...). He places him after the physician Androma-

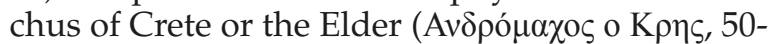
$68 \mathrm{AD}$ ) and contemporary with the physician An-

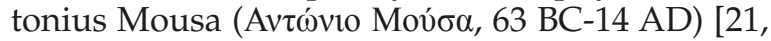
22]. Diachylon cataplasm was a small patch that sticks to the skin composed from acre juices of different plants together with a substrate of lead oxide boiled together with olive oil and water. It was applied on sheets of linen and when heated, acts as an adhesive plaster. Galen also mentions another physician and surgeon Meges of Sidon

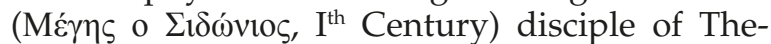

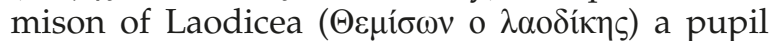

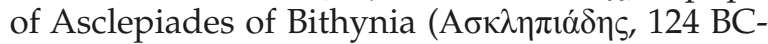

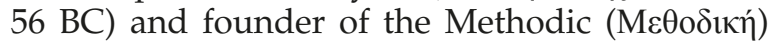
school of medicine. Galen reports about his pharmacological compound that removes inflamma- tion from the leprosy skin areas. Finally, at the II $^{\text {th }}$ century (100 AD) the Greek physician Criton (Kpí $\omega v)$ of Heraclea composed various cosmetic remedies and therefore also for leprosy use, thus mostly for the skin [22-24].

Leprosy was a very diffused illness in Europe during the medieval period, particularly between 1000 and 1400 AD. It was widely spread into Europe during the Roman conquests and the crusades, which are considered one of the main reasons for its propagation in western Europe during this period. We should mention here, the Roman emperor Flavio Valerio Aurelio Constantine or Constantine I the Great (274-337 AD) who was one of the most important figures of that period (he founded the Nova Roma or later also Constantinople) who was most likely affected by this disease. This is testified by a sacred text called the "Life of St Sylvester" and some Western sacred iconography. However it would seem that he had not the severe multi-system disease but the mild only cutaneous form [24]. Subsequently, many were the eminent doctors of the Roman Empire of the East (Byzantium) who described the illness as Oribasios

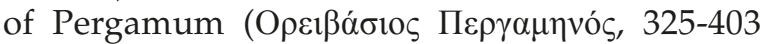

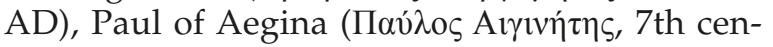
tury AD), Chrysobalantes Theophanes or Non-

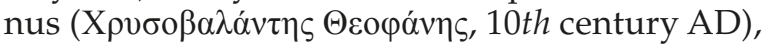

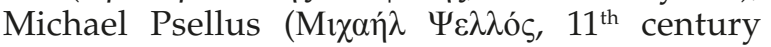

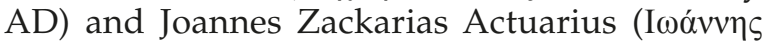

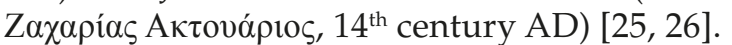

Oribasios of Pergamum who was the personal chief physician (archiatros) of the Emperor Julian the Apostate, wrote an overview of the medical

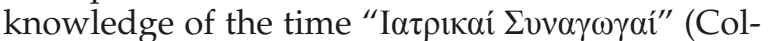
lectiones medicae) seventy volumes with comments that included his own observations for many diseases as the le leprosy. Indeed, Oribasios provides us with a precious source on the history of ancient Greek medicine and divides the disease into two clinical form: the middle form, named "leprosy" ( $\lambda \dot{\varepsilon} \pi \rho \alpha$ : skin scaly) and the severe one with multisystemic symptoms named "elephantiasis" [25-27]. Later this knowledge was transmitted to the eminent medieval doctors of Western medical schools such as those of "Schola Medica Salernitana" (Salerno, southern Italy, $9^{\text {th }}$ century) and the school of Montpellier (1220 AD, France) $[28,29]$.

In these centuries, lepers were considered carriers 
of a terrible disgrace, so they were treated inhumanly, discarded from society and strategically excluded in quarantined colonies, far enough from the cities to avoid the contagion. Other people were so scared about the infection that lepers were marked with a strong and bad social stigma, so they could not go back to their occupations and to their families. They were forced to live into the hundreds, probably in the thousands "lazar hous$e s^{\prime \prime}$, which were specific buildings to isolate sick people from the society. Into these lazar houses, lepers followed strict rules of conformity to remain; otherwise, they were asked to leave and forced to live as a homeless person. During the Middle Ages "Leper Masses" were celebrated after the diagnosis of leprosy, to declare that the afflicted one was officially dead for the rest of society. Lepers must wear bells or clappers, distinctive garments, all their personal effects were buried, sometimes their houses. Exemplary is the colored image of the manuscript "Code Lansdowne" from the $1^{\text {st }}$ quarter of the $15^{\text {th }}$ century. The image shows a leper with his bell that had to ring when they went out into the street to be recognized and so people moved away at a safe distance [30, 31]. Skeletal examinations of lepers remain in lazar houses in Denmark showed that a high percentage of people actually did have the disease, particularly their skulls did not present the anterior nasal spine [31].

\section{Leprosy's decline in Europe and the appearance in the New Continent}

After the Middle Ages, during the $14^{\text {th }}$ and $15^{\text {th }}$ centuries, the disease started a gradual decline and became a sporadic one, due to the improvement in the standard of living but also because lots of other rampant and aggressive plagues killed millions of people, such as the tuberculosis and syphilis, such as those infected with leprosy, very debilitated from the illness. These facts were the most responsible for its decline. Moreover, people infected with the Mycobacterium tuberculosis were accidentally cross-immunized against the related Mycobacterium leprae, so they developed a strong resistance to leprosy. For this reason, BCG was soon recognized to protect partly also from leprosy $[32,33]$. During the $19^{\text {th }}$ century, Hansen's disease remained with a very low prevalence in the Mediterranean countries such as England, Spain, Portugal, Italy, Greece, Turkey and in the west Russia; in the mid-1800s it disappeared from Norway and England [34].

Many historians and archaeologists suppose that leprosy, such as other bacterial infectious diseases like syphilis, was absent in the New Continent and it was first brought from the Old Continent by the Columbus' troops and then by slaves from West Africa; after it was further spread by explorers and immigrants from Europe to both North and South America and in the Pacific's islands [35-39].

An important milestone about the disease's knowledge, a part from the discovery of M. leprae by Dr. G. Armauer Hansen in 1874, was the bacterial multiplication in the mouse footpad experimented by Dr. Charles Shepard of the Centers for Disease Control in 1959 [39, 40]. Moreover, in 1968, Dr. Waldemar Kirchheimer of Carville and Dr. Eleanor Storrs of the Gulf South Research Institute inoculated the M. leprae in the nine-banded armadillo, causing a disseminated Hansen's disease in the animal's body [41-43].

Treatment of leprosy has undergone important changes over decades, from chaulmoogra oil in 1915 to the first breakthrough occurred in the 1940s with the development of the sulfone therapy (dapsone) by Dr. Guy Faget of Carville. Treatment with dapsone was very difficult: it lasted many years, often a lifetime and first bacterial-resistance started to develop in the 1960s. Rifampicin and clofazimine were later discovered in the early 1960s and then added to the treatment scheme of the "multidrug therapy" (MDT) [45, 46]. This triple combination of drugs (dapsone, rifampicin and clofazimine) is the official treatment of leprosy recommended by WHO from 1981 and provided free of costs since 1995 until 2020. It lasts for six months for pauci-bacillary and 12 months for multi-bacillary cases [1, 46, 47].

\section{DISCUSSION}

Leprosy is probably one of the oldest infectious diseases ever known in human history. Hansen's disease has been the scourge of humanity since ancient times. Its spread all over the world followed human paths of migration from the African Continent to the Asian one and to Europe, instead it appeared more recently in the New Continent. Its decline after the Middle Age was due to the raise of some of the most brutal killers in human 
history: pandemics such as cholera, syphilis, bubonic plague, influenza and smallpox.

Lepers have always been marked with a strong social stigma: people afflicted have often been ostracized by their communities and families. For example, we can find unjust and horrifying descriptions of lepers in different movies, books and novels, describing them as poor, dirty and with a lot of disgusting lesions on their skin, covered with a dark mantle to cover their bodies and their transfigured faces. Their social isolation is attested by several "Lepers home" all over the world, especially in isolated places far from the cities or even on the islands to obtain a complete seclusion. In many films and books, we can find statements and references to leprosy that imply that lepers should be avoided or avoided at all costs, using descriptions of ill people with a regrettable and offensive language. This kind of fear and scariness about leprosy has brought the use in the current language of many sayings referred to the illness, such as "don't treat me as I have leprosy!" if someone don't want to stay near another one, or "you are a moral leper" to offend someone. For all these reasons, the World Health Organization (WHO) has suggested to erase the term "leprosy" from medical literature, suggesting to use the name of Hansen's disease in order not to have such an aggressive and discriminating meaning as "leprosy". Lepers' discriminations are not an exclusive of the past; many episodes have continued to exist in each time of history, including those suffered in the last years from people afflicted both by leprosy and AIDS.

Efforts for leprosy control reached the important goal of eliminating it globally, defined as a registered prevalence of less than 1 case per 10,000 population, in 2000 [1]. This means that leprosy is not yet a disappeared disease: in fact, in 2018, there were 208,619 new leprosy cases registered globally by the WHO from 159 countries [1, 47]. In practice, the actual epidemiology of leprosy appears to be different from the official reports, with an estimating number of cases being 17 times higher than those reported officially, so, in endemic areas where people have limited access to good education, sanitation, health and social services, it remains a public health concern [48].

Leprosy is a very complex disease to eradicate because it is strongly related to poverty, lack of health facilities and education. For these reasons, the WHO elaborated in 2016 a document to describe the global strategy adopted to completely eradicate leprosy all over the world. This document, entitled "Global Leprosy Strategy 2016-2020: Accelerating towards a leprosy-free world" stresses the importance of a global political and economic coordination and effort against leprosy's cases still present in the territory in order to avoid related disabilities and other complications [49]. It refers specially to children, women, disadvantaged people living in high endemic areas, improving prevention and hygiene measures, strengthening healthcare systems, ensuring adherence to treatment and management of disabilities.

Equally important, the document tries to fight every historically rooted form of discrimination and social stigma, promoting societal inclusion of healed lepers, empowering their active involvement in leprosy services, promoting communities among persons affected by leprosy and their families to encourage integration and coalitions with other members. But, most important, it underlines the importance to support persons affected by leprosy with a free access to social and financial support services, for example to facilitate their rehabilitation in case of disabilities related to the disease, and to work towards abolishing any discriminatory law.

\section{CONCLUSIONS}

Leprosy is an age-old disease which can be considered the emblem of social inequalities and historical power of social stigma. A big effort must be made by scholars to reach a complete eradication of disease from endemic areas and by all humanity to fight against prejudice and abolish every form of discrimination. In the very long history of Hansen's disease, we hope the final episode will be the extirpation of the disease but also the suppression of a distorted mentality towards sick people and their social role. Nowadays, an important field of research regards the role of probiotics in the treatment of several infectious diseases, and encourage further investigations in this field.

\section{Funding}

None to declare.

\section{Conflict of interest}

None. 


\section{REFERENCES}

[1] World Health Organization. Leprosy. Available at https: / / www.who.int/ news-room/fact-sheets / detail/leprosy. Published on 10 September 2019. Last accessed February 21, 2020.

[2] Djelouadji Z, Raoult D, Drancourt M. Palaeogenomics of Mycobacterium tuberculosis: epidemic bursts with a degrading genome. Lancet Infect Dis. 2011; 11 (8), 64150. doi: 10.1016/S1473-3099(11)70093-7.

[3] Singh P, Benjak A, Schuenemann VJ et al. Insight into the evolution and origin of leprosy bacilli from the genome sequence of lepromatosis. Proc Natl Acad Sci USA. 2015; 7; 112 (14), 4459-64. doi: 10.1073/pnas.1421504112. [4] Vogelsang T.M. Discovery of Leprosy Bacillus. JAMA. 1963; 184 (11), 901-902. doi: 10.1001/jama.1963. 03700240093022.

[5] Robbins G, Mushrif Tipathy V, Misra VN, et al. Ancient skeletal evidence for leprosy in India (2000 B.C.). Plos One 2009; 4, 1-8. doi: 10.1371/journal.pone, 0005669.

[6] Monot M, Honoré N, Garnier T, et al. On the origin of leprosy. Science. 2005; 13; 308 (5724), 1040-2. doi: $10.1126 /$ science/1109759.

[7] Monot M, Honoré N, Garnier T, et al, Comparative genomic and phylogeographic analysis of Mycobacterium leprae. Nat Genet. 2009; 41 (12), 1282-9. doi: 10.1038/ ng. 477.

[8] Dharmendra, Leprosy in ancient Indian medicine. Int J Lepr.1947; 15 (4), 424-30.

[9] Skinsnes OK. Notes from the history of leprosy. I. Interpretive chronology of leprosy concept and practice. Int J Lepr Other Mycobact Dis. 1973; 41 (2), 220-33. Available at http:/ /ila.ilsl.br/pdfs/v41n2a12.pdf.

[10] Trautman JR. A brief history of Hansen's disease. In bulletin of the New York Academy of medicine, New York. 1984; 60 (7), 689-95. Available at https://www. ncbi.nlm.nih.gov/pmc/articles/PMC1911721/pdf/ bullnyacadmed00073-0005.pdf. Last accessed March 1, 2020.

[11] Yoeli M, Mot, the Canaanite god, as symbol of the leper. Bull N Y Acad Med. 1968; 44 (8), 1057-67.

[12] Maoshing N, The Yellow Emperor's Classic of Medicine: A New Translation of the Neijing Suwen with Commentary (Shambhala, Eds), 1995: 1-320. Last accessed March 2, 2020.

[13] Tubbs RS, Riech S, Verma K, et al. China's first surgeon: Hua Tuo (c. 108-208 AD). Childs Nerv Syst. 2011; 27, 1357. https://doi.org/10.1007/s00381-011-1423-z.

[14] May B, Tomoda T, Wang M. The life and medical practice of Hua Tuo. Pacific J Orient Med. 2000; 14: 40-5. [15] Herodotus, Book I: chapters 45 140, p51. Available at http://penelope.uchicago.edu/Thayer/E/Roman/ Texts/Herodotus/1B*.html Last accessed March 1, 2020.

[16] Cochrane RG. Biblical Leprosy, A Suggested Inter- pretation. Tyndale Press, vol. 12, issue: 4, 202-203, London 1961.https:/ /doi.org/10.1177/000608446101200412. Last accessed March 2, 2020.

[17] Bottalico L, Charitos IA, Kolveris N, et al. Philosophy and Hippocratic Ethic in Ancient Greek Society: Evolution of Hospital - Sanctuaries. Maced J Med Sci. 2019; $15 ; 7$ (19), 3353-7.

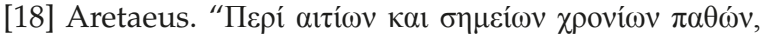

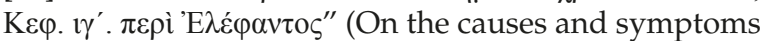
of chronic disease, in On Elephas, Book II, Chapter XIII. Available at https://www.perseus.tufts.edu/hopper/ text?doc $=$ Perseus $\% 3$ Atext $\% 3$ A1999.01.0253\%3Atext $\% 3$ Dsd\%3Apage\%3D73. Last accessed March 2, 2020.

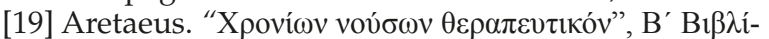

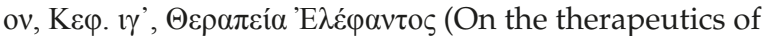
chronic disease), in Cure of Elephas, Book II, chapter XIII. Available at https: / / www.perseus.tufts.edu/hopper $/$ text?doc $=$ Perseus $\% 3$ Atext $\% 3 A 1999.01 .0253 \% 3 A t e$ xt\%3Dcd Last accessed March 2, 2020.

[20] Reed JA. Aretaeus, the Cappadocian: history enlightens the present. Diabetes. 1954; 3 (5), 419-21. doi: 10.2337 / diab.3.5.419.

[21] Karamanou M, Kyriakis KP, Androutsos G. Aretaeus of Cappadocia on leprosy's transmission. JAMA. 2013; 149 (3), 292. doi: 10.1001/jamadermatol.2013.2352 Last accessed March 2, 2020.

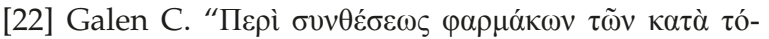
$\pi \mathrm{ov} \varsigma$, (De compositione medicamentorum per genera). Available at http://www.poesialatina.it/_ns/greek/ testi/Galenus/De_compositione_medicamentorum_ per_genera_libri_VII.html. Last accessed March 2, 2020

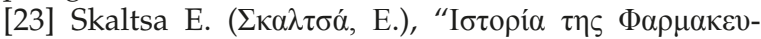

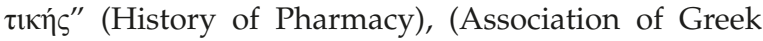
Academic Libraries, Kallipos, Eds), 2015: 91-94. Last accessed March 2, 2020.

[24] Santacroce L., Bottalico L., Charitos I.A., Greek Medicine Practice at Ancient Rome: The Physician Molecularist Asclepiades. Medicines (Basel). 2017; 12, 4 (4). doi: $10.3390 /$ medicines4040092.

[25] Stavrianeas NG, Toumbis Ioannou E, Laskaratos FM Constantine the Great and leprosy: fact or fiction? Clin Dermatol. 2009; 7, 1, 139-41. doi: 10.1016/j.clindermatol.

[26] Prioreschi PA. History of Medicine: Byzantine and Islamic medicine (Horatius press Eds). 1996: 1-49.

[27] Bennett, D. Medical practice and manuscripts in Byzantium. Soc Hist Med. 2000; 13: 279-91. doi: 10.1093/ shm/13.2.279.

[28] Gordon BL. Medieval and Renaissance Medicine (Philosophical Library Eds).1959: 1-843.

[29] Bowers BS. The Medieval Hospital and Medical Practice. AVISTA studies in the history of medieval technology, science and art, vol. 3 (Ashgate Publishing, Ltd, Eds), 2007: 1- 258.

[30] Demaitre L, Leprosy in Premodern Medicine: A Malady of the Whole Body. (JHU Press Eds). 2007:1-323. 
[31] Mac Arthur W, Mediaeval leprosy in the British Isles. Lepr Rev. 1953; 24 (1), 8-19. doi: 10.5935/03057518.19530002.

[32] Lewis ME, Roberts CA, Manchester K. Inflammatory bone changes in leprous skeletons from the medieval Hospital of St. James and St. Mary Magdalene, Chichester, England. Int J Lepr Other Mycobact Dis. 1995; 63 (1), 77-85.

[33] Merle CS, Cunha SS, Rodrigues LC. BCG vaccination and leprosy protection: review of current evidence and status of BCG in leprosy control. Expert Rev Vaccines. 2010; 9 (2), 209-22. doi: 10.1586/erv.09.161.

[34] Coppola M, van den Eeden SJF, Robbins N, et al. Vaccines for leprosy and tuberculosis: opportunities for shared research, development, and application. Front Immunol. 2018; 26; 9, 308. doi: 10.3389/fimmu.2018.00308.

[35] Irgens LM. Epidemiological aspects and implications of the disappearance of leprosy from Norway; some factors contributing to the decline. Lepr Rev. 1981; 52 (Suppl. 1), 147-65. doi: 10.5935/03057518.19810066.

[36] Santacroce L, Bottalico L, Topi S, Castellaneta F, Charitos IA. The "Scourge of the Renaissance". A short review about Treponema pallidum infection. Endocr Metab Immune Disord Drug Targets. 2019. doi: 10.2174/1 871530319666191009144217.

[37] Martin DL, Goodman AH. Health conditions before Columbus: paleopathology of native North Americans. West J Med. 2002; 176 (1), 65-8.

[38] Guerra F. The European-American exchange. Hist Philos Life Sci. 1993; 15 (3), 313-27.

[39]BianchinePJ, RussoTA. Theroleofepidemicinfectious diseases in the discovery of America. Allergy Proc.1992; 13 (5), 225-32. doi: 10.2500/108854192778817040.

[40] Blondiaux J, Naji S, Bocquet-Appel JP, et al. The lep- rosarium of Saint-Thomas d'Aizier: The cementochronological proof of the medieval decline of Hansen disease in Europe? Int J Paleopathol. 2016; 15: 140-151. doi: 10.1016/j.ijpp.2015.02.005.

[41] Shepard CC. The experimental disease that follows the injection of human leprosy bacilli into footpads of mice. J Exp Med. 1960; 112, 445-54. doi: 10.1084/ jem.112.3.445.

[42] Faget GH, Pogge RC, Johansen FA, et al. The promin treatment of leprosy. A progress report, Int J Lepr Other Mycobact Dis. 1966; 34 (3), 298-310.

[43] Kirchheimer WF, Storrs EE. Attempts to establish the armadillo (Dasypus novemcinctus Linn.) as a model for the study of leprosy. I. Report of lepromatoid leprosy in an experimentally infected armadillo. Int J Lepr Other Mycobact Dis. 1971; 39 (3), 693-702.

[44] Rees RJW, Waters MFR, Weddell AGM. Experimental lepromatous leprosy. Nature. 1967; 215, 599-602. [45] Browne SG, Treatment of leprosy with B663: Appraisal of the pilot trial after three years. Lepr. Rev. 1965; 36:13-15. doi: 10.5935/0305-7518.19650004

[46] WHO. Guidelines for the diagnosis, treatment and prevention of leprosy. 2018. Available at https:/ /www. who.int/lep/resources/9789290226383/en/. Last accessed March 10, 2020.

[47] Herbert B. Allen, Samuel L. Moschella. The Role of Rifampin in Leprosy: Leprosy Through a New Lens. JAMA Dermatol. 2017; 153 (3), 261-2. doi: 10.1001/jamadermatol.2016.5506.

[48] Paredes CF, Montes de Oca Sanchez G, White C. Global Leprosy Status in 2020: Still Losing Touch. Ann Acad Med Singapore. 2020; 49 (1), 1-2.

[49] WHO. The Global Leprosy Strategy 2016-2020: Accelerating towards a leprosy-free world. Available at https: / /apps.who.int/iris/handle/10665/254907. Last accessed April 2, 2020. 